\title{
RŪKYMO YPATUMAI TARP PSICHIATRIJOS IR NEPSICHIATRIJOS STACIONARUOSE GYDOMŲ PACIENTU LIETUVOJE
}

\author{
Alvydas Navickas, Justina Valančiūtė, Petras Navickas, Laura Lukavičiūtė, Vita Danilevičiūtė \\ Vilniaus universiteto Medicinos fakultetas
}

Raktažodžiai: rūkymas, psichiatrijos stacionarai, nepsichiatrijos stacionarai, Lietuva.

\section{Santrauka}

Tyrimo tikslas. Išsiaiškinti rūkymo paplitimo ypatumus ịvairiuose Lietuvos gydymo ịstaigų stacionaruose.

Tyrimo metodas. Buvo atliktas vienmomentis, kiekybinis, anoniminis, anketinis tyrimas psichiatrijos ir nepsichiatrijos stacionaruose Vilniuje, Klaipedoje ir Šiauliuose. Apklausti 228 asmenys: 113 psichiatrijos $(49,6 \%)$ ir 115 nepsichiatrijos $(50,4 \%)$ stacionaruose besigydančių asmenų, tarp jų moterų buvo $116(50,9 \%)$ ir vyrų $112(49,1 \%)$. Respondentų amžius buvo nuo 18 iki $92(54,5 \pm 18,5)$ metų.

Tyrimo rezultatai. Psichiatrijos stacionaruose rūkančių asmenų gydosi 3,5 karto daugiau $-48,7 \%$, nei nepsichiatrijos stacionaruose $13,9 \%(\mathrm{p}=0,001)$. Iš visų rūkančių pacientų psichiatrijos ir nepsichiatrijos stacionaruose beveik dvigubai dažniau rūko vyrai, atitinkamai $65,5 \%$ ir $62,5 \%$. Net $96,3 \%$ rūkančiu psichiatrijos ir 75\% nepsichiatrijos stacionarų respondentų tęsia rūkymą besigydydami stacionare $(\mathrm{p}=0,008)$. Psichikos sutrikimus gydantys pacientai surūkydavo vidutiniškai 5,6 cigaretèmis daugiau, t. y. vidutiniškai po 16,3 cigaretes per dieną lyginant su gydančiais somatinius sutrikimus 10,7 . Net 55,8\% psichiatrijos stacionarų respondentų pažymèjo rūkantys vidutinio stiprumo cigaretes, o nepsichiatrijos stacionarų pacientai dažniau rūkè lengvas $-43,8 \%(p=0,013)$. Dažniausiai rūkantys pacientai rūko lauke: psichiatrijos $-46,9 \%$, nepsichiatrijos $-75,0 \%$. Be to psichiatrijos skyrių pacientai rūkè tualetuose ir net palatose. Pagrindiniai du rūkymą palaikantys faktoriai abejose grupèse buvo tie patys: tai raminantis ir gerinantis nuotaiką poveikis, o psichiatrijos stacionaruose gydomi rūka- liai išskyrẻ dar ir vaistų šalutinius reiškinius mažinanti poveikị. Taip pat atkreipiamas demesys it tai, kad $85,5 \%$ rūkančių ir 23,8\% nerūkančių asmenų psichiatrijos stacionaruose pažymèjo reikalingumą specialių rūkyti skirtų vietų, kai nepsichiatrijos stacionaruose dauguma rūkančių $68,7 \%$ bei $100 \%$ nerūkančių pasisakè priešingai $(p=0,001)$. Svarbu atkreipti dèmesi i tai, kad nei vienam pacientui nebuvo nustatyta su rūkymo problemomis susijusi diagnozè ir nebuvo skirtas gydymas. Metant rūkyti psichiatrijos skyrių respondentai daugiausia vilčių teikè rūkymo metimo konsultacijoms, gydymui, elektroninèms cigaretėms, o nepsichiatrijos skyrių: elektroninèms cigaretèms, griežtiems draudimams ir gydymui. İdomu pažymèti, kad literatūrai apie rūkymo žalą abiejų grupių rūkoriai teikè mažiausiai reikšmès.

Išvados. Lietuvoje stacionaruose gydomiems pacientams rūkymo problema yra aktuali, ypač tarp psichiatrijos stacionarų ligonių. Psichiatrijos stacionarų pacientai turi sunkesnius rūkymo požymius ir patiria daugiau diskomforto sprendžiant rūkymo problemą. Rūkymo sukeltai psichikos ir elgesio sutrikimų diagnostikai, profilaktikai ir gydymui nèra skiriama adekvataus dèmesio, priemonių ir resursų. Sąlygų rūkyti nebuvimas veda ị rūkančių ir nerūkančių pacientų žeminimą, diskriminaciją ir psichiatrijos stigmatizavimą.

\section{İvadas}

Rūkymas yra viena dažniausių priklausomybių tarp psichikos sutrikimus turinčių asmenų [1]. Psichikos ligomis sergantys asmenys, kaip ir kiti rūkantys, turi padidejusią riziką mirti nuo rūkymo sukeltų ligų. Nustatyta, kad psichikos sutrikimų turintieji net 2-4 kartus dažniau rūko nei asmenys bendroje populiacijoje, kas lemia ir didesni plaučių onkologinių ligų paplitimą tarp jų [1-4]. Rūkymas, alko- 
holio vartojimas, menka dantu priežiūra taip pat padidina ir burnos bei gerklų véžio riziką [3]. Prochaska ir kiti savo tyrimo [4] metu pastebejo, kad dažniau rūko jaunesni, vieniši, bipoliniu afektiniu sutrikimu, depresija ar kitomis priklausomybės ligomis sergantys pacientai. Kito tyrimo metu Etter su bendraautoriais [2] pastebejo, kad schizofrenija ar schizoafektiniu sutrikimu sergantys pacientai buvo labiau priklausomi nuo tabako nei rūkantys bendroje populiacijoje. Taip pat minèti pacientai rūkè 6 cigaretèmis per dieną daugiau, pirmają cigaretę ryte surūkydavo 30 minučių anksčiau, bei daug mažiau pasitikèjo savo jègomis planuodami mesti rūkyti [2].

Rūkymo uždraudimas gydymo ịstaigose daugelyje JAV valstijų bei daugelyje Europos šalių turejjo sumažinti dūmų ekspoziciją tarp pacientų, lankytojų, darbuotojų, taip pat paskatinti mesti rūkyti, tačiau šis draudimas aplenkẻ daugumą psichiatrijos ligoninių, nes buvo pastebèta, kad rūkymas ligoniams padeda valdyti ligos simptomus. Be to, manoma, kad draudimas rūkyti tarp šių pacientų yra sunkiai igyvendinamas, nes nikotino abstinencija jiems gali sukelti padidèjusị dirglumą bei ažitaciją, kas žymiai sutrikdytų darbą psichiatrijos skyriuose $[4,8]$. Kito tyrimo metu Glyn ir Sussman pastebejo, kad dauguma schizofrenija sergančių pacientų parūkę jautė mažiau nerimo bei buvo labiau atsipalaidavę. Taip pat tyrimai [7] parodè didesnį atkryčių kiekị metusiems rūkyti schizofrenija sergantiems asmenims. Rūkančių teigimu [6], nikotino vartojimas skatina atsipalaidavimą ir malonias emocijas, mažina nerimą, pyktį, depresiją, mažina socialinę atskirtị, padeda bendrauti. Rūkantiems nikotino poveikyje išsiskyręs azoto oksidas sumažina streso simptomus, didina posinapsinio dopamino kiekị [5]. Tačiau nevertètų pamiršti, kad cigarečių dūmai padidina CYP1A2 fermentų aktyvumą, dèl to sumažejja daugelio vaistu, pvz., olanzapino, klozapino koncentracija kraujyje. Rūkymas taip pat susijęs ir su padidejjusiu haloperidolio, flufenazino klirensu. Dèl šių priežasčių rūkantiems schizofrenija sergantiems asmenims gali prireikti didesnių antipsichotikų dozių nei nerūkantiems $[1,2,6]$.

Nepaisant rūkymo žalingo poveikio ir aktyvaus skatinimo mesti rūkyti, Prochaska ir kiti, atlikę tyrimą JAV San Francisko Psichiatrijos ligoninèse, nustate, kad psichikos sveikatos centruose iš tiesų labai mažai dèmesio skiriama rūkymui ir priklausomybei nuo tabako. Nei vienam iš 250 pacientų nebuvo nustatyta priklausomybè tabakui bei rūkymo statusas nebuvo įtrauktas ị gydymo planą. Kitame tyrime su panašia tiriamujų grupe nustatyta, kad 52\% nebuvo padrąsinti ligoninès personalo mesti rūkyti [4].

Darbo tikslas: išsiaiškinti rūkymo paplitimo ypatumus psichiatrijos ir nepsichiatrijos Lietuvos gydymo ịstaigų stacionaruose.

\section{Tyrimo objektas ir metodika}

$2014 \mathrm{~m}$. vasario - balandžio ménesiais buvo atliktas kiekybinis, anoniminis, vienmomentis tyrimas psichiatrijos ir nepsichiatrijos stacionaruose Vilniuje, Klaipedoje ir Šiauliuose, taikant anketinès apklausos metodą, siekiant ivvertinti rūkančiu pacientu paplitimą bei ypatumus. Apklausai naudota anoniminè anketa, kurioje buvo pateikti klausimai tiek rūkantiems, tiek nerūkantiems asmenims. Apklausa vykdyta raštu. Iš 228 tinkamai užpildytų anketu $113(49,6 \%)$ buvo iš psichiatrijos ligoninių ir $115(50,4 \%)$ iš nepsichiatrijos ligoninių ( 1 lentelè), tarp jų moterų buvo $116(50,9 \%)$ ir vyrų $112(49,1 \%)$. Respondentų amžius buvo nuo 18 iki $92(54,5 \pm 18,5)$ metų. Tyrimui naudota anketa buvo sudaryta remiantis PSO „Tabako klausimai apklausoms" [11].

Respondentai klausimyne turejo pateikti 52 atsakymus. Bendroje dalyje nurode savo amžių, lytį, išsilavinimą, gyvenamają vietą (miestas ar kaimas), stacionaro pavadinimą, gydymo stacionare trukmę. Pagal rūkymo ịpročius jie buvo suskirstyti ị rūkančius ir nerūkančius. Rūkantieji turèjo įrašyti per dieną surūkomų cigarečių skaičių, bendrą rūkymo trukmę, nurodyti cigarečiu stiprumą - lengvos (nikotino koncentracija iki $0,6 \mathrm{mg}$ ), vidutinio stiprumo (nikotino koncentracija 0,7-0,9 mg) ir stiprios (nikotino koncentracija $>1 \mathrm{mg}$ ), nurodyti kiek vidutiniškai išleidžia pinigų už vieną cigarečių pakelị, atsakyti, ar rūko šio gydymo stacionare metu. Taip pat reikejjo atsakyti, ar, jų manymu, ligoninèse reikalingi specialiai rūkyti skirtos patalpos (vietos). Tirti rūkoriai turejjo pažymėti kur: lauke, tualete, koridoriuje, palatoje ar kitose vietose rūko; taip pat nurodyti rūkymo priežastis: teikia malonumą, pagerina nuotaiką, būdas pabendrauti su kitais, lengvina ligos simptomus, veikia raminamai, jaučia nenugalimą potraukį rūkyti, bandè mesti, bet nepavyko, trūksta aplinkinių palaikymo, metus rūkyti pablogèjo liga bei kitos priežastys; taip pat ar norètų mesti rūkyti bei kas, jų manymu, jiems padètų spręsti šią problemą: kramtomas tabakas, elektroninès cigaretès, literatūra prieš rūkymą, griežtas draudimas rūkyti ligoninèse, rūkymo metimo konsultacijos, gydymas prieš rūkymą. Šiuose klausimuose galima buvo pasirinkti kelis pacientui tinkančius atsakymus. Buvo pateikti klausimai, ar buvo konsultuotas dèl rūkymo problemų ir ar skyriuje galèjo rasti informaciją apie rūkymo prevenciją. Atsakymų i klausimą dažnis vertintas procentais, jų pasiskirstymo statistiniam reikšmingumui nustatyti naudotas chi kvadrato $\left(\chi^{2}\right)$ kriterijus. Rezultatai buvo laikomi statistiškai reikšmingais, kai paklaidos tikimybė $\mathrm{p}<0,05$. Tarpusavio ryšiams įvertinti taikyta Pearson'o rangine koreliacija. Duomenų statistinei analizei naudotas SPSS 17. 


\section{Tyrimo rezultatai}

Nustatyta (1 lentelè), kad psichiatrijos stacionaruose rūkančių asmenų gydosi net 3,5 karto daugiau nei nepsichiatrijos stacionaruose $(p=0,001)$ : iš 113 apklaustu psichiatrijos stacionaruose gydomų asmenų rūkè 55 (48,7\%), kai nepsichiatrijos stacionaruose iš 115 apklaustuju rūkè tik $16(13,9 \%)$. Iš visų rūkančių pacientų psichiatrijos ir nepsichiatrijos stacionaruose beveik dvigubai dažniau rūkè vyrai, atitinkamai $65,5 \%$ ir $62,5 \%$.

Tyrimo metu buvo lygintas rūkančiu ir nerūkančiu asmenų amžius psichiatrijos ir nepsichiatrijos stacionaruose. Rūkančių pacientų psichiatrijos ir nepsichiatrijos stacionaruose vidutinis amžius buvo panašus, atitinkamai $44 \pm 1,8$

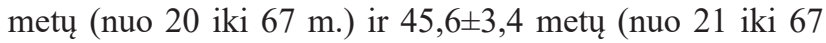
$\mathrm{m}$.). Nerūkančių asmenų vidutinis amžius psichiatrijos stacionaruose buvo 46,4 $\pm 2,2$ (nuo 18 iki $76 \mathrm{~m}$.), kai nepsichiatrijos stacionaruose dažniau nerūkè vyresni asmenys (vidutiniškai 67,8 1 1,6 metų amžiaus, nuo 23 iki 92 m.) (2 lentelè).

Rūkantys ir nerūkantys asmenys psichiatrijos ir nepsichiatrijos stacionaruose pagal išsilavinimą ir gyvenamą vietą reikšmingai nesiskyrè, daugiausia buvo vidurinio išsilavinimo respondentų bei dažniau buvo gyvenančių mieste. Svarbu pažymèti, kad psichiatrijos stacionarų pacientai gydèsi žymiai ilgiau nei nepsichiatrijos stacionaruose (2 lentelè).

Tyrimo duomenys parode, kad psichiatrijos stacionaro pacientai rūko vidutiniškai 5,6 cigaretèmis daugiau - vidutiniškai 16,3 $\pm 1,3$ (nuo 3 iki 50) per dieną, o nepsichiatrijos stacionaruose rūkaliai surūkè vidutiniškai po $10,7 \pm$ 1,4 (nuo 4 iki 20 cigarečių) per dieną. Nustatyta, kad psichiatrijos stacionarų pacientai buvo linkę rūkyti stipresnes, turinčias daugiau nikotino cigaretes nei nepsichiatrijos stacionaru pacientai. Net 54,5\% psichiatrijos stacionaru

1 lentelè. Respondentai pagal stacionarus, rūkančius ir nerūkančius pacientus bei lytị (2014 m., Lietuva)

PSR - psichiatrijos stacionaru respondentai; NPSR - nepsichiatrijos stacionaru respondentai; RP - rükantys pacientai; NP - nerükantys pacientai; Vyr - vyrai; Mot - moterys.

\begin{tabular}{|c|c|c|c|c|c|c|c|}
\hline \multicolumn{8}{|c|}{ Iš viso 228 respondentai } \\
\hline \multicolumn{4}{|c|}{ PSR $113(49,6 \%)$} & \multicolumn{4}{|c|}{ NPSR $115(50,4 \%)$} \\
\hline \multicolumn{2}{|c|}{ RP $55(48,7 \%)$} & \multicolumn{2}{|c|}{ NP $58(51,3 \%)$} & \multicolumn{2}{|c|}{ RP $16(13,9 \%)$} & \multicolumn{2}{|c|}{ NP $99(86,1 \%)$} \\
\hline Vyr. & Mot. & Vyr. & Mot. & Vyr. & Mot. & Vyr. & Mot. \\
\hline $36(65,5 \%)$ & $19(34,5 \%)$ & $18(31 \%)$ & $40(69 \%)$ & $10(62,5 \%)$ & $6(37,5 \%)$ & $48(48,5 \%)$ & $51(51,5 \%)$ \\
\hline
\end{tabular}

2 lentelè. Psichiatrijos ir nepsichiatrijos stacionarų rūkančių ir nerūkančių pacientų palyginimas pagal amžių, išsilavinimą, gyvenamąją vietą, gydymosi trukmę, požiūrị i i rūkymo patalpas (2014 m., Lietuva)

\begin{tabular}{|l|c|c|c|c|c|c|}
\hline Kriterijus & Nr. & Variantai & $\begin{array}{c}\text { PSR RP } \\
\mathbf{N}=\mathbf{5 5}\end{array}$ & $\begin{array}{c}\text { PSR NP } \\
\mathbf{N}=\mathbf{5 8}\end{array}$ & $\begin{array}{c}\text { NPSR RP } \\
\mathbf{N}=\mathbf{1 6}\end{array}$ & $\begin{array}{c}\text { NPSR NP } \\
\mathbf{N}=\mathbf{9 9}\end{array}$ \\
\hline Amžius & & m \pm SN & $44,0 \pm 1,8$ & $46,4 \pm 2,2$ & $45,6 \pm 3,4$ & $65,8 \pm 1,6$ \\
\hline $\begin{array}{l}\text { Išsilavini- } \\
\text { mas }\end{array}$ & 1. & $\begin{array}{c}\text { Nebaigtas } \\
\text { vidurinis }\end{array}$ & $3(5,5 \%)$ & $2(3,4 \%)$ & $1(6,3 \%)$ & $19(19,2 \%)$ \\
\hline & 2. & Vidurinis & $24(43,6 \%)$ & $24(41,4 \%)$ & $8(50,0 \%)$ & $40(40,4 \%)$ \\
\hline & 3. & $\begin{array}{c}\text { Nebaigtas } \\
\text { aukštasis }\end{array}$ & $2(3,6 \%)$ & $3(5,2 \%)$ & 0 & $3(3 \%)$ \\
\hline & 4. & Aukštesnysis & $13(23,6 \%)$ & $10(17,2 \%)$ & $4(25,0 \%)$ & $11(11,1 \%)$ \\
\hline $\begin{array}{l}\text { Gyvenamo- } \\
\text { ji vieta }\end{array}$ & 5. & Aukštasis & $13(23,6 \%)$ & $19(32,8 \%)$ & $3(18,7 \%)$ & $26(26,3 \%)$ \\
\hline & 2. & Miestas & $49(89,1 \%)$ & $47(81 \%)$ & $12(75 \%)$ & $79(79,8 \%)$ \\
\hline $\begin{array}{l}\text { Gydymosi } \\
\text { trukmé }\end{array}$ & 1. & $<7 \mathrm{~d}$. & $16(29,1 \%)$ & $17(29,3 \%)$ & $8(50 \%)$ & $71(71,7 \%)$ \\
\hline & 2. & $7-14 \mathrm{~d}$. & $17(30,9 \%)$ & $17(29,3 \%)$ & $5(31,3 \%)$ & $20(20,2 \%)$ \\
\hline & 3. & $15-30 \mathrm{~d}$. & $14(25,5 \%)$ & $19(32,8 \%)$ & $2(12,5 \%)$ & $5(5,1 \%)$ \\
\hline & 4. & $>30 \mathrm{~d}$. & $8(14,5 \%)$ & $5(8,6 \%)$ & $1(6,3 \%)$ & $3(3 \%)$ \\
\hline $\begin{array}{l}\text { Reikia rū- } \\
\text { kymo patal- } \\
\text { pos (vietos) }\end{array}$ & 1. & Taip & $47(85,5 \%)$ & $14(23,8 \%)$ & $5(31,3 \%)$ & 0 \\
\cline { 2 - 7 } & 2. & Ne & $8(14,5 \%)$ & $44(76,2 \%)$ & $11(68,7 \%)$ & $99(100 \%)$ \\
\hline
\end{tabular}


pacientų pažymèjo rūkantys vidutinio stiprumo cigaretes, o nepsichiatrijos stacionarų pacientų $68,8 \%$ pažymèjo rūkantys lengvas cigaretes $(\mathrm{p}=0,013)$. Tuo metu kai abiejų tipų stacionarų respondentų rūkymo stažas buvo panašus vidutiniškai apie 20 metų (3 lentelè).

Respondentų atsakymai apie rūkomų cigarečių kainą parode tendenciją, kad psichiatrijos stacionarų pacientai dažniau rūkè brangesnes cigaretes nei nepsichiatrijos stacionarų. 55,8\% psichiatrijos stacionarų pacientų rūkè cigaretes kainavusias $6-8 \mathrm{Lt}$ arba 1,7-2,4 Eur, kai nepsichiatrijos stacionaru pacientai dažniau, t. y. 43,8\%, rinkosi pačias pigiausias cigaretes iki $6 \mathrm{Lt}$ arba 1,7 Eur.

Daugumai pacientų rūkymas - nenutrūkstamas procesas, nepaisant ligoninèse galiojančių draudimų. Net 96,3\% apklaustujų rūkančiujų psichiatrijos skyriuose bei $75 \%$ nepsichiatrijos stacionarų pacientų rūkẻ gydymo stacionare laikotarpiu (p $=0,008$ ) (3 lentelè). Apklausos metu pacientai pažymèjo pagrindines vietas, kur jie rūkè gydymo metu. Duomenys parode, kad psichiatrijos stacionarų pacientai rūkè ìvairesnèse vietose: lauke $46,9 \%$, tualete $-20,3 \%$, net palatose $-4,7 \%$ arba koridoriuose $-3,1 \%$ bei kitose vietose $-25,0 \%$, tokiu būdu dažnai itraukdami i pasyvu rūkymą net ir nerūkančius pacientus bei medicinos personalą. Priešingai nei psichiatrijos stacionaruose, nei vienas nepsichiatrijos stacionaru pacientas nepažymejjo rūkantis tualete ar palatoje, dauguma jų rūkè lauke $-75,0 \%$ ar koridoriuje $-18,8 \%$. Galbūt dèl žymiai dažnesnio rūkymo paplitimo bei nerūkančiu įtraukimo ị pasyvų rūkymą net $85,5 \%$ rūkančių ir 23,8\% nerūkančių asmenu psichiatrijos stacionaruose pasisakè, kad gydymo istaigose reikalingos specialios rūkyti skirtos vietos, kai nepsichiatrijos stacionaruose dauguma rūkančių $68,7 \%$ bei

3 lentelè. Psichiatrijos ir nepsichiatrijos stacionarų pacientų rūkymo ypatumai (2014 m., Lietuva)

* - respondentų atsakymų skaičius yra nurodytas Iš viso.

\begin{tabular}{|c|c|c|c|c|}
\hline Kriterijus & Nr. & Variantai & $\begin{array}{c}\begin{array}{c}\text { PSR RP } \\
=55\end{array}\end{array}$ & NPSR RP $=16$ \\
\hline Cigaretès / dieną & & & $16,3 \pm 1,3$ & $10,7 \pm 1,4$ \\
\hline Rūkymo metai & & & $20,8 \pm 1,7$ & $19,6 \pm 2$ \\
\hline \multirow{3}{*}{ Cigarečių stiprumas } & 1. & Lengvos & $15(27,3 \%)$ & $11(68,8 \%)$ \\
\hline & 2. & Vidutinio stiprumo & $30(54,5 \%)$ & $4(25,0 \%)$ \\
\hline & 3. & Stiprios & $10(18,2 \%)$ & $1(6,2 \%)$ \\
\hline \multirow[t]{3}{*}{ Pakelio kaina } & 1. & $<6 \mathrm{Lt}(<1,74 €)$ & $12(21,2 \%)$ & $7(43,8 \%)$ \\
\hline & 2. & $6-8 \mathrm{Lt}(<1,74-2,32 €)$ & $30(55,8 \%)$ & $4(25,0 \%)$ \\
\hline & 3. & $>8 \mathrm{Lt}(>2,32 €)$ & $13(23 \%)$ & $5(31,3 \%)$ \\
\hline \multirow[t]{2}{*}{ Ar rūko stacionare? } & 1. & Taip & $53(96,4 \%)$ & $12(75,0 \%)$ \\
\hline & 2. & $\mathrm{Ne}$ & $2(3,6 \%)$ & $4(25,0 \%)$ \\
\hline \multirow[t]{6}{*}{ Rūkymo vieta* } & 1. & Laukas & $30(46,9 \%)$ & $12(75,0 \%)$ \\
\hline & 2. & Tualetas & $13(20,3 \%)$ & 0 \\
\hline & 3. & Koridorius & $2(3,1 \%)$ & $3(18,8 \%)$ \\
\hline & 4. & Palata & $3(4,7 \%)$ & 0 \\
\hline & 5. & Kita & $16(25,0 \%)$ & $1(6,3 \%)$ \\
\hline & & Iš viso & $64(100 \%)$ & $16(100 \%)$ \\
\hline \multirow[t]{11}{*}{ Rūkymo priežastis* } & 1. & Teikia malonumą & $13(11,4 \%)$ & $3(13,6 \%)$ \\
\hline & 2. & Pagerina nuotaiką & $15(13,2 \%)$ & $5(22,7 \%)$ \\
\hline & 3. & Būdas bendrauti & $10(8,8 \%)$ & $3(13,6 \%)$ \\
\hline & 4. & Lengvina simptomus & $15(13,2 \%)$ & 0 \\
\hline & 5. & Veikia raminamai & $29(25,4 \%)$ & $5(22,7 \%)$ \\
\hline & 6. & Potraukis rūkyti & $5(4,4 \%)$ & $1(4,5 \%)$ \\
\hline & 7. & Bando mesti & $17(14,9 \%)$ & $2(9,1 \%)$ \\
\hline & 8. & Trūksta palaikymo & $2(1,8 \%)$ & $2(9,1 \%)$ \\
\hline & 9. & $\begin{array}{l}\text { Nerūkant pablogėja } \\
\text { liga }\end{array}$ & $1(0,9 \%)$ & 0 \\
\hline & 10. & Kitos & $7(6,1 \%)$ & $1(4,5 \%)$ \\
\hline & & Iš viso & $114(100 \%)$ & $22(100 \%)$ \\
\hline \multirow[t]{7}{*}{ Rūkymo metimo būdai* } & 1. & Kramtomasis tabakas & 0 & 0 \\
\hline & 2. & Elektroninès cigaretès & $14(23,3 \%)$ & $4(25,0 \%)$ \\
\hline & 3. & Literatūra & $8(13,3 \%)$ & $1(6,3 \%)$ \\
\hline & 4. & Griežti draudimai & $5(8,3 \%)$ & $4(25,0 \%)$ \\
\hline & 5. & $\begin{array}{l}\text { Rūkymo metimo kon- } \\
\text { sultacijos }\end{array}$ & $17(28,3 \%)$ & $3(18,7 \%)$ \\
\hline & 6. & Rūkymo gydymas & $16(26,7 \%)$ & $4(25,0 \%)$ \\
\hline & & Iš viso & $60(100 \%)$ & $16(100 \%)$ \\
\hline \multirow{2}{*}{$\begin{array}{l}\text { Ar konsultuotas dèl } \\
\text { rūkymo problemų? }\end{array}$} & 1. & Taip & 0 & 0 \\
\hline & 2. & $\mathrm{Ne}$ & $55(100 \%)$ & $16(100 \%)$ \\
\hline \multirow{2}{*}{$\begin{array}{l}\text { Ar skyriuje yra informacija } \\
\text { skirta rūkymo prevencijai? }\end{array}$} & 1. & Taip & 0 & 0 \\
\hline & 2. & $\mathrm{Ne}$ & $55(100 \%)$ & $16(100 \%)$ \\
\hline
\end{tabular}




\section{4}

visi nerūkantys pasisakè priešingai $(\mathrm{p}=0,001)$, teigè, $\mathrm{kad}$ tokių vietų nereikia.

Kitame anketos klausime rūkantys turejjo pažymèti visas priežastis, kodèl jie rūko (3 lentelè). Didžioji dalis rūkančių psichiatrijos stacionaruose, t. y. 25,4\% nurode, kad rūkymas juos veikia raminamai, dar išskyrè nuotaiką gerinanti, pašalinius vaistų reiškinius mažinantị veikimą, o vienas teigè, kad nutraukus rūkymą blogèja psichikos būklè. Nepsichiatrijos stacionaru pacientai taip pat dažniausiai nurodè raminamajị ir nuotaiką gerinantị rūkymo poveikị po $22,7 \%$, bet nei vienas nepažymėjo pašalini vaistų poveikio mažinimą ar nutraukus rūkymą blogejjančią sveikatą. İdomu atkreipti dèmesį, kad retas abiejų grupių respondentas kaip rūkymo priežastị pažymėjo potraukị rūkyti (3 lentelè).

Net kas šeštas psichiatrijos ir kas aštuntas nepsichiatrijos stacionaro pacientas norejo mesti rūkyti (3 lentelè). Daugumos psichiatrijos pacientų manymu, efektyviausias būdas metant rūkyti būtų rūkymo metimo konsultacijos $28,3 \%$ bei gydymas nuo rūkymo $26,7 \%$, o nepsichiatrijos stacionaro pacientai dar palaiko griežtų draudimų idèją. Abiejų grupių pacientams atrodo svarbi ir elektroninių cigarečių pagalba. İdomu tai, kad abiejų grupių pacientai mažai reikšmès teikia literatūrai apie rūkymo žalą. Svarbus atlikto tyrimo rezultatas: nustatyta, kad pacientai negauna jokių konsultacijų ir literatūros apie rūkymo prevenciją iš juos gydančio personalo ir rūkymo problemos neįtraukiamos ị pagalbos planą.

\section{Diskusija}

Atliktas tyrimas parode, kad Lietuvoje psichiatrijos ir nepsichiatrijos stacionarų pacientų rūkymo ypatumai yra gana skirtingi. Rūkymo problemos žymiai dažnesnès tarp psichiatrijos skyrių pacientų. Net kas antras ligonis susiduria su šiuo kenkiančiu sveikatai potraukiu, kuris turi aiškiai sunkesnị pobūdị nei nepsichiatrijos stacionarų pacientams. Jie rūko daugiau ir stipresnes cigaretes, dẻl jų rūkymo dažniau kenčia kiti pacientai ir personalas. Panašiai, kaip ir užsienio mokslininku atliktuose tyrimuose, galima patvirtinti, kad psichiatrijos stacionarų pacientai jaučia didesni poreikị rūkyti dèl nikotino raminamojo poveikio, pašalinius reiškinius mažinančio poveikio bei dèl to, kad nutraukus nikotino vartojimą jaučiamas sveikatos pablogèjimas. Todèl suprantama kai kurių mokslininkų rekomendacija esant psichinès būklès pablogèjimui prievarta nekeisti paciento ipročio rūkyti, o tai rekomenduojama bandyti esant pagrindinio susirgimo atoslūgiui. Kadangi psichiatrijos stacionaruose pacientams taikomas griežtesnis stebejimas, dažniau tenka praleisti laiką uždarose patalpose, todèl rūkymo sąlygos būna ypač komplikuotos, net kartais rūkoma palatose, koridoriuje ar tualete. Tai ne tik žemina pacientą, kenkia jo orumui, diskriminuoja ir stigmatizuoja pacientą ir psichiatrinę pagalbą, bet ir kenkia aplinkiniams pacientams, neretai juos erzina, sukelia pasipiktinimą, nusiskundimus ir taip pat didina artimujų neigiamą požiūrị i psichiatriją. Problemą dar daugiau padidina tai, kad psichiatrijos stacionarų pacientų gydymosi trukmė yra žymiai reikšmingesnè už nepsichiatrijos pacientų. Todèl tai, kad psichiatrijos stacionaruose nèra tinkamai ịrengtų rūkyti vietų sukelia didžiuli sveikatos priežiūros konfliktą su visais stacionaruose gydomais pacientais. Lietuvos Respublikos Rūkymo kontrolès įstatymas [11] draudžia rūkyti sveikatos priežiūros įstaigose. Todèl kyla didžioji dalis su rūkymu susijusių problemų pacientams, personalui, neįmanoma civilizuotai spręsti susidariusių problemų, įrengti rūkyti skirtas patalpas arba vietas.

Šiuolaikinès techninès galimybès leidžia ịrengti gerai ventiliuojamas rūkymo vietas. Šiose vietose galima būtų tikslingai laikyti pacientams skirtą informaciją apie rūkymo žalą, prevenciją ir gydymą. Personalas lengviau galètų identifikuoti turinčius rūkymo problemų pacientus, ịvertintų rūkymo keliamą žalą ir galètų lengviau išvengti rūkymo problemų hipodiagnostikos klaidų bei atskleisti gydomųjų priemoniu poreikị, planuoti lèšas joms įsigyti.

Psichikos ir elgesio sutrikimų dèl tabako gydymas yra svarbus stacionariai gydomiems kitomis psichikos ligomis sergantiems asmenims. Aktyvi, rekomendacijomis paremta sutrikimų nuo tabako diagnostika ir gydymas turètų būti viena iš psichikos sutrikimus turinčių pacientų priežiūros dalių [9]. Europos psichiatrų asociacija rekomenduoja [10] dokumentuoti psichikos sutrikimų turinčių asmenų rūkymo statusą, ivertinti, ar nèra kontraindikacijų nutraukti tabako vartojimą. Paciento būsena rūkymo metimo metu turètų būti stabili, be jokios ūmios patologijos, psichiatrinis gydymas neturètų būti neseniai koreguotas ar planuojamas keisti. Labai svarbu konsultuoti pacientą rūkymo metimo klausimais, supažindinti, kokių nutraukimo simptomų mesdamas rūkyti jis gali sulaukti, aptarti alternatyvius būdus, kaip susidoroti su stresinemis situacijomis ar nerimu bei tabako priklausomybès gydymo būdus.

\section{Rekomenduojama}

1. Lietuvos Respublikos Tabako kontrolès istatyme (2003 m. lapkričio mèn. 20 d. Nr. IX-1840) pataisyti Trečio skirsnio 19 straipsnio Tabako gaminių ribojimas 1 punktą taip: Lietuvos Respublikoje rūkyti draudžiama: 1) ,...sveikatos priežiūros įstaigose ir jų teritorijose (išskyrus specialiai rūkyti ịrengtose patalpose (vietose), ...“.

2. Rūkantiems pacientams diagnozuoti komorbidinius psichikos ir elgesio sutrikimus dèl tabako vartojimo (remiantis TLK-10-AM kodas F17). 
3. Psichikos ir elgesio sutrikimų dèl tabako vartojimo problemų sprendimą įtraukti ị gydymo planą.

\section{Išvados}

1. Lietuvoje stacionaruose gydomiems pacientams rūkymo problema yra aktuali, ypač tarp psichiatrijos stacionarų pacientų.

2. Psichiatrijos stacionarų pacientai turi sunkesnius rūkymo požymius ir patiria daugiau diskomforto sprendžiant rūkymo problemą nei somatinių stacionarų pacientai.

3. Rūkymo sukeltai psichikos ir elgesio sutrikimų diagnostikai, profilaktikai ir gydymui nèra skiriama adekvataus dèmesio, priemonių ir resursų.

4. Rūkyti sąlygų nebuvimas veda ị rūkančių ir nerūkančių pacientų žeminimą, diskriminaciją ir psichiatrijos stigmatizavimą.

\section{Literatūra}

1. Lasser K, Boyd JW, Woolhandler S, Himmelstein DU, McCormick D, Bor DH. Smoking and mental illness: a populationbased prevalence study. JAMA, 2000;284:2606-2610. http:// jama.jamanetwork.com/article.aspx?articleid $=193305$ http://dx.doi.org/10.1001/jama.284.20.2606

2. Etter M, Mohr S, Garin C, Etter JF. Stages of change in smokers with schizophrenia or schizoaffective disorder and in the general population. SchizophrBull, 2004;30:459-468. http:// schizophreniabulletin.oxfordjournals.org/content/30/2/459 http://dx.doi.org/10.1093/oxfordjournals.schbul.a007092

3. Lichtermann D, Ekelund J, Pukkala E, Tanskanen A, Lonnqvist $\mathrm{J}$. Incidence of cancer among persons with schizophrenia and their relatives. Arch Gen Psychiatry, 2001;58:573-578. http:// archpsyc.jamanetwork.com/article. aspx?articleid $=481785$

http://dx.doi.org/10.1001/archpsyc.58.6.573

4. Prochaska JJ, Gill P, Hall SM. Treatment of tobacco use in an inpatient psychiatric setting. PsychiatrServ, 2004;55:12651270. http://ps.psychiatryonline.org/doi/full/10.1176/appi. ps.55.11.1265

http://dx.doi.org/10.1176/appi.ps.55.11.1265

5. Vleeming W, Rambali B, Opperhuizen A. The role of nitric oxide in cigarette smoking and nicotine addiction. // Nicotine Tob Res, 2002 Aug;4(3):341-348. http://www.ncbi.nlm.nih. gov/pubmed/12215243

http://dx.doi.org/10.1080/14622200210142724

6. Šagud M, Mihaljevic-Pleš A, Much-Šeler D. Smoking and schizophrenia.// Psychiatria Danubina, 2009;21(3):371-375. http://www.ncbi.nlm.nih.gov/pubmed/19794359

7. Lyon E. R.A Review of the effects of nicotine on schizophrenia and antipsychotic medications.//Psychiatric Services 1999; http://www.ncbi.nlm.nih.gov/pubmed/10506305

8. Prochaska JJ, Rossi JS, Redding CA, Rosen AB, Tsoh JY, Humfleet GL. et al. Depressed smokers and stage of change: implications for treatment interventions. Drug Alcohol Depend, 2004;76:143-151. http://www.drugandalcoholdependence. com/article/S0376-8716\%2804\%2900128-0/abstract

http://dx.doi.org/10.1016/j.drugalcdep.2004.04.017

9. Fiore M, Jaen C, Baker T. Treating tobacco use and dependence: 2008 update. Clinical Practice Guideline US: Department of Health and Human Services Public Health Service; 2008. http:// bphc.hrsa.gov/buckets/treatingtobacco.pdf

10. Ruter T, Bobes J, De Hert M. EPA Guidance on tobacco dependence and strategies for smoking cessation in people with mental illness. European Psychiatry 2014; 29:65-82.

http://dx.doi.org/10.1016/j.eurpsy.2013.11.002

11. Lietuvos Respublikos Tabako kontrolès ịstatymas $2003 \mathrm{~m}$. lapkričio 20 d. Nr. IX-1840. Vilnius http://www3.lrs.lt/pls/ inter3/oldsearch.preps $2 ? \mathrm{a}=223448 \& \mathrm{~b}=$

\section{PECULARITIES OF SMOKING IN PSYCHIATRIC AND NON-PSYCHIATRIC WARDS IN LITHUANIA A. Navickas, J. Valančiūtė, P. Navickas, L. Lukavičiūtė, V. Danilevičiūtè}

Key words: smoking, psychiatric wards, non-psychiatric wards, Lithuania.

\section{Summary}

Objective: To find out the prevalence of smoking in various departments of Lithuanian hospitals.

Methods: A cross-sectional quantitative anonymous questionnaire study of psychiatric and non-psychiatric inpatients in Vilnius, Klaipeda and Siauliai hospitals. 228 people were interviewed: 113 in psychiatric hospitals (49.6\%) and 115 in non-psychiatric inpatients (50.4\%). 50.9\% respondents were females (116) and $49.1 \%$ males (112). The age of respondents varied from 18 to 92 $(54.5 \pm 18.5)$.

Results: In psychiatric wards were 3.5 times more smoking patients $(48.7 \%)$ than in non-psychiatric wards $(13.9 \%)(\mathrm{p}=0.001)$. Males smoked nearly two times more than females $-65.5 \%$ of smokers were male in psychiatric hospitals, while $62.5 \%$ of smokers were male in non-psychiatric hospitals. People with mental disorders smoked 16.3 cigarettes per day compared to non-psychiatric patients who smoked 10.7 cigarettes per day. $55.8 \%$ of psychiatric patients smoked medium-strength cigarettes, while $43.8 \%$ of nonpsychiatric patients smoked light cigarettes $(\mathrm{p}=0.013)$. It was found that $96.3 \%$ of patients in psychiatric wards smoked even during their hospitalization period, along with $75 \%$ of non-psychiatric patients who reported smoking in hospital territories $(\mathrm{p}=0.008)$. While hospitalized, most respondents smoked outside: $57.7 \%$ of psychiatric smokers, $75.0 \%$ of non-psychiatric smokers. Also psychiatric hospitals patients smoked in toilets and even in wards. They continued smoking because it calmed them and improved their mood, psychiatric patients also remarking that smoking relieved the side effects of treatment. It is important that $85.5 \%$ of smokers and $23.8 \%$ of non-smokers in psychiatric wards commented on the necessity for special places to be designated for smoking, contrasting with $68.7 \%$ of smokers and $100 \%$ of non-smokers in non-psychiatric wards who commented to the contrary $(\mathrm{p}=0.001)$. Of importance, 


\section{6}

none of the respondents in this study were hospitalized due to a diagnosis associated with smoking or were receiving any treatment associated with it. Psychiatric respondents considered that the best ways to stop smoking were stop-smoking consultations, treatment, electronic cigarettes, while non-psychiatric considered electronic cigarettes, treatment and a strict prohibition of smoking to be most effective. It is interesting to note that neither group smokers gave much importance to literature against smoking.

Conclusions. Smoking is a very prevalent problem in Lithuanian wards, especially amongst psychiatric patients. Patients in psychiatric wards suffer from severe smoking-related symptoms and experience more difficulties solving smoking associated problems. There is a lack of adequate attention, tools and resources for the diagnosis, prevention and treatment of smoking-related mental and behavioural disorders. The lack of smoking conditions lead to smoking and non-smoking patients' humiliation, discrimination and stigmatization of psychiatry.

Correspondence to: alvydas.navickas@mf.vu.lt

Gauta 2016-02-01 